\title{
PENDIDIKAN ISLAM DI ZAWIYAH PADA MASA KESULTANAN BUTON ABAD KE-19
}

\author{
Syarifuddin Nanti \\ Ahmad M. Sewang \\ Muzakkir \\ Program Magister Pascasarjana UIN Alauddin Makassar 2018 \\ Email: lafudy@gmail.com
}

\begin{abstract}
Abstrak: Zawiyah sebagai institusi pendidikan Islam pada masa kesultanan Buton merupakan hasil adaptasi antara ajaran Islam dan tradisi masyarakat lokal, dicirikan dengan bangunan sebagai tempat pembelajaran agama Islam dalam bidang tasawuf dan fikih. Didirikan pada awal abad ke-19 (kesembilan belas) di masa pemerintahan Sultan Muhammad Idrus Kaimuddin sampai masa Sultan Muhammad Umar (1824/1851-1885/1906 M). Terdapat empat Zawiyah pada masa kesultanan Buton, dibangun sesuai dengan nama pendirinya, yaitu Zawiyah Sultan Muhammad Idrus Kaimuddin, Zawiyah H. Abdul Ganiu (Kenepulu Bula), Zawiyah Muhammad Nuh (Kanepulu Bente) dan Zawiyah Sultan Muhammad Umar (1885-1906 M). Pelaksanaan pendidikan Islam di Zawiyah bersifat tradisional dan sentralistik atau cenderung bersifat struktural. Materi pembelajarannya memuat dua unsur yaitu ilmu tasawuf, dan ilmu fikih. Ilmu tasawuf yang meliputi tasawuf tarekat dan tasawuf teosofi atau falsafi. Sedangkan ilmu fikih mencakup kaidah uṣu 1 dan fikih, atau meliputi ibadah mahdah dan muamalah. Metode pembelajaran yang paling menonjol di Zawiyah adalah metode suluk dalam tasawuf. Hubungan antara mursyid dan murid di Zawiyah dilandasi semangat kepercayaan yang diimplementasikan melalui tingkah laku dan perbuatan sehari-hari. Adapun peran Zawiyah terhadap perkembangan pendidikan Islam di Buton sebagai wadah dalam menanamkan kesadaran berfikir tentang hakekat keislaman bagi masyarakat Buton yang ada di wilayah keraton, sekaligus sebagai bentuk syiar ajaran Islam yang mesti melekat dalam kehidupan masyarakat Buton secara keseluruhan.
\end{abstract}

Keywords: Pendidikan Islam; Zawiyah dan Kesultanan Buton Abad Ke-19 


\section{PENDAHULUAN}

Zawiyah pada masa kesultanan Buton merupakan hasil adopsi dari ajaran Islam yang di bawah oleh para sufi selama proses Islamsiasi dan diadaptasikan ke dalam masyarakat Buton untuk memahami ajaran Islam tersebut. Sebagai pusat pendidikan Islam pada saat itu, Zawiyah telah memberi warna dan corak tersendiri bagi kehidupan masyarakat Buton. Hanya saja Zawiyah yang merupakan tempat bertemunya guru dan murid menimba ilmu pendidikan tentang ajaran-ajaran Islam masih berkutat pada masyarakat keraton saja. Padahal wilayah kekuasaan kesultanan Buton meliputi wilayah Kadie dan Barata. Sehingga tidak semua masyarakat yang masuk dalam wilayah Kesultanan Buton menerima ilmu pendidikan Islam secara langsung di Zawiyah. Hal inilah yang membuat dikotomis pendidikan Islam pada saat itu bersifat idiologis stratifikasi sosial, dalam artian hanya para bangsawan yang memiliki garis keturunan raja (sultan), yakni kaumu dan walaka sementara kelas masyarakat biasa, yakni papara (rakyat jelata). dan batua (budak) tidak mendapatkan pendidikan Islam di Zawiyah. ${ }^{1}$

Berdasarkan pandangan tersebut, maka ajaran-ajaran Islam di Zawiyah yang berkembang pada masyarakat Buton merupakan warisan turun-temurun yang digunakan dan dijadikan sebagai tradisi keilmuan pendidikan Islam. Meskipun ajarannya pada era kesultanan bersifat eksklusif, karena terjadi dikotomi yang bernuansa ideologi stratifikasi sosial. Namun pengaruh ajarannya dapat merubah tradisi kepercayaan masyarakat Buton dan membentuk nilai-nilai keislaman, baik yang bersifat insidental maupun transidental. Seperti penetapan nilai-nilai Islam yang dituangakan dalam martabat tujuh sebagai undang-undang pemerintahan, dan falsafah pobinci-binci kuli yang melambangkan semangat persaudaraan antara sesama manusia sebagai wujud implementasi keruhanian dalam tradisi keislaman masyarakat Buton.

Berdasarkan latar belakang yang telah dikemukakan, maka pokok masalah dalam penelitian ini adalah Bagaimana "Pendidikan Islam di Zawiyah pada Masa kesultanan Buton?" Berdasarkan pokok masalah tersebut kemudian dirinci ke dalam beberapa sub masalah yang dirumuskan sebagai berikut:

1. Bagaimana gambaran umum institusi Zawiyah pada masa kesultanan Buton?

2. Bagaimana pelaksanaan pendidikan Islam di Zawiyah pada masa kesultanan Buton?

3. Bagaimana peran Zawiyah terhadap perkembangan pendidikan Islam di Buton?

${ }^{1}$ Abd. Rahim Yunus, Posisi Tasawuf dalam Sistem Kekuasaan di Kesultanan Buton Pada Abad Ke-19 (Jakarta: Indonesian-Netherlands cooperation in Islmic Studies ( INIS), 1995), h. 102. 


\section{TINJUAN TEORETIS}

\section{A. Selayang Pandang tentang Zawiyah}

Untuk lebih menelusiri jejak Zawiyah, terlebih dahulu diuraikan makna Zawiyah itu sendiri. Secara etimologi Zawiyah berasal dari bahasa Arab, yaitu

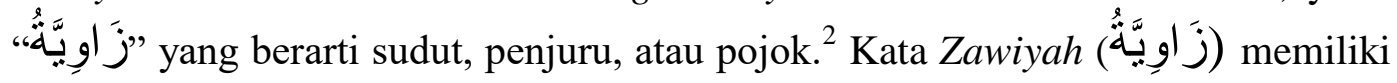
akar kata zawa-yazwi (زَ)َوَي - يَزْوِي) yang berarti menjauhkan, atau melarang,

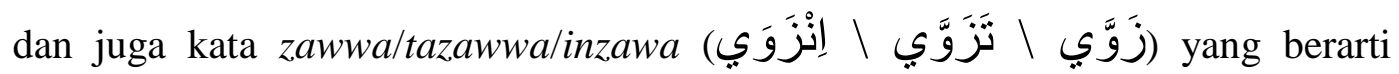
mengasingkan diri kesudut, menyudut. ${ }^{3}$ Kata ini digunakan oleh kaum sufi sebagai istilah yang menerangkan kegiatan pembelajaran yang dilakukannya.

Zawiyah pada awalnya merujuk pada sudut bangunan, seringkali masjid, tempat sekelompok orang berkumpul untuk mendengarkan pengajaran seorang syaikh. Zawiyah seperti ini terdapat misalnya di Jami' al-Athiq yang dibangun oleh Amru bin al-Ash begitu ia menaklukkan Fusthath. Pada Zawiyah ini ilmu fiqh seperti ilmu-ilmu yang lain sesuai dengan bidang syaikhnya merupakan bagian dari kegiatan pewarisan ilmu. ${ }^{4}$ Zawiyah ini adalah bangunan yang lebih kecil dibandingkan dengan Khanqah (salah satu bangunan dikelola oleh para sufi). Zawiyah adalah bangunan kecil yang sederhana, yang dipusatkan di seputar seorang syaikh, yang semula adalah tidak permanen karena sering syaikhnya adalah seorang pendatang. ${ }^{5}$

Pelembagaan Zawiyah sebagai model pendidikan Islam tidak secara jelas disebutkan dalam sejarah, hanya saja lembaga ini muncul sebagai bagian yang tidak terpisahkan dari gelombang ajaran-ajaran sufisme yang berkembang dalam dunia Islam.

Zawiyah dibangun oleh seorang syaikh pada tarekat tertentu. Pembangunan ini diharapkan mampu memperbanyak anggota dari tarekat tersebut, karena bangunan ini lebih kecil dibanding dengan Khanqah maka ia tidak mempunyai seperangkat aturan yang jelas. Zawiyah di Mesir menjelang penaklukan Turki Usmani dikelompokkan ke dalam dua jenis yaitu:

1. Zawiyah tradisional yang mempunyai hubungan erat dengan penguasa (Mamluk).

\footnotetext{
${ }^{2}$ Ahmad Warson, Al-Munawwir, Kamus Arab Indonesia, telaah. Ali Ma’șun, Zainal Abidin Munawwir, (Cet. XIV; Surabaya, Pustaka Progres, 1997), h. 595.

${ }^{3}$ Ahmad Warson, Al-Munawwir, Kamus Arab Indonesia, telaah. Ali Ma'șun, Zainal Abidin Munawwir, h. 595.

${ }^{4}$ Maqrizi, "Mawa'id II", h. 429, dalam Hasan Asari, Menyingkap Keemasan Islam: Kajian atas Lembaga-lembaga Pendidikan Islam (Bandung: Mizan, 1994), h. 96.

${ }^{5}$ J. Spencer Trimigham, The Sufi Orders in Islam, ter. Lukman Hakim, Mazhab Sufi (Bandung: Pustaka, 199), h. 173.
} 
2. Zawiyah yang lebih independen,

Berbeda dengan Zawiyah tradisional, Zawiyah yang independen, sering menjalankan fungsinya sebagai masjid dan Ribath, yaitu menyediakan fasilitas ibadah, makanan dan perlindungan bagi orang miskin. Contoh dari bagian kedua di atas adalah Zawiyah Syaikh Ibnu Riwam yang selalu menolak bantuan. ${ }^{6}$

Zawiyah yang pada awalnya hanya berupa bangunan kecil, dalam perkembangannya menurut Fernandes dalam Donald P. Little menyebutkan bahwa banyak "bangunan Zawiyah yang berupa aula yang besar, sebagai tempat pertemuan para sufi. Kemegahan dan kebesaran bangunan Zawiyah ini ditentukan oleh kemashuran dari syaikhnya itu sendiri. Sehingga pendirian Zawiyah ini banyak dirikan oleh syaikh itu sendiri". 7 Syaikh yang telah wafat biasanya dimakamkan di Zawiyahnya yang akan menjadi tempat ziarah bagi para pengikut tarekatnya.

Jonathan Barkey menejelaskan bahwa Zawiyah merupakan institusi informal sebagai tempat berkumpulnya para Sufi yang dibimbing oleh seorang syaikh. Ia menyebutkan bahwa term Zawiyah ini lebih fleksibel, terkadang dikonotasikan sebagai pojokan sebuah masjid besar, tapi terkadang juga merujuk pada pojokan masjid kecil yang digunakan oleh para Sufi untuk beribadah dan melakukan riyāẹah" (latihan). ${ }^{8}$

Berdasarkan pengertian di atas, maka Zawiyah dapat dikatakan sebagai lembaga pendidikan Islam yang kegiatan pembelajarannya bersifat sufistik, sesuai dengan ajaran pendirinya, mengutamakan nilai esoteris (batin) dari pada nilai eksetoris (lahir) sebagai bentuk latihan pengembangan diri dan pembentukan karakter menuju ma'rifat Allah yang sejati.

\section{B. Kesultanan Buton}

1. Mengenal Kesultanan Buton

Kesultanan Buton merupakan dua kata yang mengacu pada defenisi yang berbeda. Istilah Kesultanan sendiri digunakan sebagai bentuk kata yang bermakna kerajaan atau kekuasaan. ${ }^{9}$ Biasanya istilah ini identik dengan simbol kekuasaan Islam, sehingga istilah kerajaan dalam Islam diganti dengan istilah kesultanan

${ }^{6}$ Al-Nuaymi, “Al-Dāris fĩ Tārikh al-Madāris (Beirut: Dār al-Kutūb al-'Ilmīyah, 1990)”, dalam Hasan Asari, Menyingkap Keemasan Islam: Kajian atas Lembaga-lembaga Pendidikan Islam, h. 97.

${ }^{7}$ Donald P. Little, "The Nature Of Khanqah, Ribath and Zawiyah", dalam Islamic Studies to Charles Adams, ed (Leiden: E.J. Brill, 1990), h. 93.

${ }^{8}$ Jonathan Barkey, The Transmission of Knowledge in Medieval Cairo; a Social History of Islamic Education (Pringeton: Pringeton Uneversity Press, 1992), h. 58.

${ }^{9}$ Pius A Partanto, M Dahlan al-Barry, Kamus Ilmiah Populer (Surabaya: Arkaloka, tt), h. 737. 
yang lebih melekat dengan tradisi Islam. Di dalam Kamus Ilmiah Populer, kata kesultanan berasal dari kata "sultan" yang berarti raja Islam. ${ }^{10}$ Penggunaan kata sultan sebagai simbol kekuasaan raja Islam berakar kata dari tradisi bahasa Arab yakni șultân (سُلْطَنَن) yang berarti "raja, atau penguasa". ${ }^{11}$ Dengan demikian, kesultanan dapat berarti kekuasaan sultan atau kekuasaan raja Islam.

Kata "Buton", digunakan sebagai nama Kesultanan, yaitu pulau Buton. ${ }^{12}$ Di pulau inilah terletak pusat pemerintahan Kesultanan Buton. Nama ini berasal dari nama jenis pohon yaitu pohon butun. ${ }^{13}$ Tidak diketahui, sejak kapan pulau itu bernama demikian. Yang pasti, sejak masa Gajah Mada menjadi patih Kerajaan Majapahit, Buton telah dikenal di Jawa. Hal ini dapat diketahui dari Kakawin Nagarakretagama Karangan Mpu Prapanca. Prapanca dalam kitabnya menyebut sumpah Gajah Mada yang dikenal dengan "Sumpah Palapa". Dalam kitab tersebut telah ditemukan nama Butun sebagai bagian dari Kerajaan Majapahit pada masa kekuasaan Gadjah Mada. ${ }^{14}$

Berdasarkan informasi Mpu Prapanca tersebut, dapat dimahami bahwa Buton, sejak zaman Majapahit atau sebelum Islam masuk di daerah Buton sekitar pertengahan abad ke-16, telah dikenal di daerah luar. Selain kitab Nagarakretagama sebagai sumber sejarah pertama yang menyebut nama Buton, seorang pelaut Portugal Tome Pires juga menyebut nama Buton ketika ia menceritakan pelayarannya di perairan nusantara pada tahun 1512-1515. ${ }^{15}$ Menurutnya sebagaimana yang dikutip oleh Muh. Ide Apurines, bahwa "ia berangkat dari Singapura ke Maluku melalui Borneo, Makassar dan Buton". 16 Informasi ini menunjukan bahwa ketika itu Buton telah dikenal oleh pelaut-pelaut yang melintasi perairan nusantara, termasuk orang asing. Dengan demikian, maka istilah Kesultanan Buton dapat diartikan sebagai kekuasaan raja Islam yang ada di pulau Buton, atau kekuasaan raja Islam Buton.

2. Interaksi Tasawuf dalam Kesultanan Buton

\footnotetext{
${ }^{10}$ Pius A Partanto, M Dahlan al-Barry, Kamus Ilmiah Populer, h. 737.

${ }^{11}$ Ahmad Warson, Al-Munawwir, Kamus Arab Indonesia, telaah. Ali Ma'șun, Zainal Abidin Munawwir, h. 650.

${ }^{12}$ Ligtvoet, "Beschrijing en Geschiedenis van Buton", BKI, Vol. 26, (1878), h. 1.

${ }^{13}$ J.C. Anceaux, Wolio dictionary-Wolio-English-Indonesia (Foris Publication Holand, 1987), h. 25. Lihat juga Poerwadarminta. Kamus Umum Bahasa Indonesia, 1978, h. 25.

${ }^{14}$ Bambang Pramudito, Kitab Negara Kartagama: Sejarah Tata Pemerintahan dan Peradilan Keraton Majapahit (Yogyakarta: Gelombang Pasang, 2006), h. 191.

${ }^{15}$ Armado Corteseo, “The Suma Oriental of Tome Pires”. Vol. 1, (1944), h. 220.

${ }^{16}$ F.s.a. Declerqie. "Bijdragen tot de Kennis der Residentie Ternate". 1890, h. 154. Lihat juga Muh. Ide Apurines, "Pratik Pemerintahan pada Kesulanan Buton Tahun 1540-1960 Masehi", https://www.academia.edu/11742287/Praktik_Pemerintahan_Kesultanan_Buton_Pada_tahun_154 0-1960_Masehi, (Akses 4 Januari 2018).
} 
Menelusuri bagaimana interaksi tasawuf dengan kehidupan masyarakat Indonesia, khsusunya pada masa kesultanan Buton, terlebih dahulu mengetahui bagaimana perjumpaan tasawuf dengan kesultanan Buton, dan bagaimana kontribusi tasawuf terhadap Kesultanan Buton.

Islam masuk di Sulawesi Tenggara, seperti di kepulauan Buton dibawah oleh para pedagang muslim dari Gujarat, India, dan kaum muslim kebangsaan Arab. Hal ini mengingat Buton adalah tempat yang strategis bagi masuk dan keluarnya arus perdagangan, baik dari pulau Jawa maupun Sulawesi Selatan menuju Maluku, maupun sebaliknya, maka Buton sebagai pelabuhan tempat persinggahan dari Jawa kebelahan timur Indonesia, terutama ke Maluku atau Ternate. Sejak tahun 1542 M (948 H) Buton merupakan satu-satunya kerajaan Islam yang resmi di Sulawesi Tenggara. Hal ini ditandai dengan terbangunnya sistem pemerintahan dengan sistem kesultanan. ${ }^{17}$

Buton sebelumnya, masih merupakan kerajaan yang penuh dengan nilainilai Hindu yang hidup dalam masyarakatnya. Nilai-nilai Hinduistik secara perlahan hilang atau mengalami akulturasi dengan nilai-nilai agama Islam yang datang kemudian. Namun pada saat syiar Islam tiba di Buton yang dibawah oleh Syaikh Abdul Wahid pada abad ke-14, maka raja Buton yang ke-6 yang bernama Lakilaponto masuk Islam dan pemerintahannya pun beralih status menjadi kesultanan. Kendati Islam telah diterima sebagai agama orang Buton secara formal, namun praktek-praktek pra-Islam masih juga hidup di sebagian masyarakat Islam Buton. Misalnya, adanya falsafah sosial yang menguat yang disebut "Pobinci-Binciki Kuli", artinya masing-masing orang saling mencubit kulitnya sendiri. Falsafah sosial orang Buton pra-Islam ini memiliki empat nilai Islami yakni: Pomae-maeka, yaitu nilai saling menghargai menyegani antara anggota masyarakat, seperti menjaga kehormatan dan martabat antara sesama anggota masyarakat. Pomaa-maasiaka, artinya saling mengasihi dan menyayangi antara anggota masyarakat Buton. Popia-piara, artinya nilai saling menjaga perasaan antara sesama anggota masyarakat dan Poangka-angkataka, artinya saling mengangkat derajat dan martabat antara sesama anggota masyarakat. ${ }^{18}$

Kontribusi tasawuf terhadap Kesultanan Buton tentu saja menjadi bagian yang tidak terpisahkan dengan proses masuknya Islam di tanah Buton. Hal ini

\footnotetext{
${ }^{17}$ Muh. Abdullah, Naskah Keagamaan dan Relevansinya dengan proses Islamisasi Buton Abad ke-14 hingga 16: Naskah Dunia (Bau-Bau: Penerbit Respect, 2009), h. 188.

${ }^{18}$ Moersidi, "Mengungkap Nilai-Nilai Kepemimpinan Buton Sebelum dan Sesudah Datangnya Agama Islam", Makalah Pada Kerukunan Mahasiswa Indonesia Buton, (1990). Dalam Mahrudin, "Kontribusi Falsafah Pobinci-Binciki Kuli Masyarakat Islam Buton Bagi Dakwah Islam Untuk Membangun Karakter Generasi Muda Indonesia”, Jurnal Dakwah, Vol. XV, no. 2, (2014), h. 342-343.
} 
disebabkan karena ajaran-ajaran tasawuf yang berkembang di Kesultanan Buton adalah hasil adaptasi dari ajaran-ajaran Islam yang berkembang di Arab dan di Indonesia (Nusantara). Ajaran-ajarannya juga berpengaruh terhadap tradisi di Kesultanan Buton, meskipun tidak semua tradisi Islam di Nusantara dapat diadaptasikan dengan tradisi Islam yang ada di Buton. Dari berbagai pandangan di atas, dapat disimpulkan bahwa perkembangan dunia Islam dalam tradisi Kesultanan Buton khususnya ajaran tasawuf tidak hanya dimasuki melalui jalurjalur kekuasaan tetapi juga melalui jalur dialog atau dakwah dengan berbagai macam metode. Salah satunya adalah pendirian institusi Zawiyah sebagai model pendidikan Islam saat itu.

\section{III.METODOLOGI PENELITIAN}

Jenis penelitian ini adalah kualitatif dengan menggunakan teknik wawancara untuk medapatkan data yang ada di lapangan, dan penelusuran dokumen-dokumen berupa naskah karya tulis yang dihasilkan oleh pendiri-pendiri Zawiyah, kemudian dikombinasikan dengan landasaan teori yang telah dibangun dalam penelitian ini.

\section{HASIL PENELITIAN DAN PEMBAHASAN}

\section{A. Gambaran Umum Institusi Zawiyah pada Masa Kesultanan Buton}

Keberadaan Zawiyah pada masa kesultanan Buton dimulai sejak awal abad XIX pada masa Sultan Muhammad Idrus Kaimuddin, ada juga yang menyebutkan bahwa Zawiyah dibangun di akhir abad XVII dan di awal abad XVIII yang didirikan oleh Sultan La Jampi yang bergelar Qāim al-Ḍīin Tua (1763-1788), merupakan kakek dari Sultan Muhammad Idrus Kaimuddin, namun bekas dan dokumen-domumen sejarah yang ditinggalkannya masih menjadi pertanyaan sampai sekarang ini. Hal ini disebabkan, karena pada masa Sultan La Jampi memerintah kesultanan Buton, tradisi tulisan belumlah semasif pada masa Sultan Muhammad Idrus Kaimuddin. Terkait itu di katakan oleh Imran Kudus, bahwa:

Zawiyah pada masa Sultan La Jampi bisa saja merupakan cikal bakal Zawiyah yang ada pada pemerintahan kesultanan Buton, karena di masa itu ajaran dan aliran tasawuf telah berkembang pesat, hanya saja Zawiyah yang didirikannya tidak meninggalkan karya-karya tasawuf sesuai dengan aliran pendirinya yang disinyalir beraliran tarekat Qadariyah oleh karena itu keberadaanya masih dipertanyakan. ${ }^{19}$

Istilah Zawiyah pada hakekatnya dirujuk dari ajaran tasawuf yang menggambarkan pola pembelajaran kaum sufi berada di pojok-pojok masjid

\footnotetext{
${ }^{19}$ Imran Kudus, sejarawan dan budayawan Buton, Wawancara, Baubau, Tanggal 23 Juni 2018.
} 
melakukan ritus berupa amalan-amalan zikir yang telah diberikan oleh mursyidnya untuk disemayamkan ke dalam lautan spritualisme batin sebagai jembatan perjumpaan antara sang hamba dengan Tuhannya. ${ }^{20}$ Sementara itu, Zawiyah di masa kesultanan Buton identik dengan sebuah bangunan, awalnya untuk menyebarkan ajaran tasawuf sesuai dengan aliran pendirinya, namun dalam perkembangannya ajaran-ajaran fikih juga mendominasi dalam Zawiyah. $^{21}$ penyebutan Zawiyah sebagai sebuah institusi selalu disandingkan dengan nama pendirinya, hal ini untuk membedakan antara Zawiyah yang satu dengan yang lainnya. terdapat 4 (empat) Zawiyah di masa kesultanan Buton yang dapat diidentifikasi sampai dengan penelitian ini di laksanakan (2018), yaitu: Zawiyah Sultan Muhammad Idrus Kaimuddin, Zawiyah H. Abdul Ganiu (Kanepulu Bula), Zawiyah Muhammad Nuh (Kanepulu Bente), dan Zawiyah Sultan Muhammad Umar. $^{22}$

Pendirian Keempat Zawiyah tersebut, tidak secara pasti dijelaskan dan disebutkan dalam beberapa literatur dan wawancara yang dilaksanakan, hanya saja disinyalir, bahwa keempatnya didirikan pada awal abad ke-19 (sembilan belas) sebagaimana yang dikatakan oleh Imran Kudus bahwa "Zawiyah di Buton didirikan pada awal abad XIX pertama kali oleh Sultan Muhammad Idrus Kaimuddin". ${ }^{23}$ Hal serupa dikatakan juga oleh La Ode Muhammad Anshari Idris dan H. La Ode Muhammad Kariu bahwa:"Keberadaan Zawiyah pada masa kesultanan Buton di awal abad ke-19". ${ }^{24}$ Karena diyakini bahwa dua tokoh utama (Sultan Muhammad Idrus Kaimuddin dan H. Abdul Ganiu) merupakan ulama Buton yang hidup dalam masa yang sama, sementara Muhammad Nuh dan Sultan Muhammad Umar, merupakan keturunan dari dua figur tersebut.

Sultan Muhammad Idrus Kaimuddin dan H. Abdul Ganiu, merupakan sosok pribadi yang akrab satu sama lain. Keduanya dikenal oleh masyarakt Buton tidak hanya sebagai tokoh politik, melainkan juga ulama yang kharismatik melahirkan karya-karya yang monumental, baik dalam bidang tasawuf, fikih, sastra maupun pemerintahan. Dengan adanya dua figur tersebut pemerintahan

${ }^{20}$ Abd. Rahim Yunus, Posisi Tasawuf dalam Sistem Kekuasaan di Kesultanan Buton pada Abad ke-19, h. 72.

${ }^{21}$ Imran Kudus, Sejarawan dan Budayawan Buton, Wawancara, Baubau, Tanggal 23 Juni 2018.

${ }^{22}$ Imran Kudus, Sejarawan dan Budayawan Buton, Wawancara, Baubau, Tanggal 23 Juni 2018.

${ }^{23}$ Imran Kudus, Sejarawan dan Budayawan Buton, Wawancara, Baubau, Tanggal 23 Juni 2018.

${ }^{24}$ LM Anshari Idris dan LM Kariu, Tokoh Budaya dan Tokoh Agama di Buton, Wawancara, Baubau, Tanggal 26 dan 28 Juni 2018. 
kesultanan Buton meraih puncak keemasannya pada abad ke-19 (kesembilan belas).

Secara pasti tahun kelahiran dua figur tersebut tidak dinyatakan dengan jelas, namun diperkirakan lahir pada seperempat akhir abad ke-18 (kedelan belas). Hal itu diketahui karena Muhammad Idrus Kaimuddin memangku jabatan sultan pada tahun $1824^{25}$ pada usianya sekitar 40 tahun(1824-1851). Sementara H. Abdul Ganiu menjabat sebagai kanepulu membantu Sultan Muhammad Idrus Kaimuddin, oleh sebab itu ia juga dikenal dengan kanepulu bula (suatu jabatan di pemerintahan Kesultanan Buton, bertindak sebagai penesehat sultan dan tuan hakim sara). ${ }^{26}$

Muhammad Nuh (bergelar Kanepulu Bente) dan Sultan Muhammad Umar yang bergelar Qāim al-Dīn IV (1885-1906), keduanya juga merupakan figur ulama yang hidup dalam masa yang sama dengan Sultan Muhammad Idrus Kaimuddin dan H. Abdul Ganiu. Kendati demikian, Sultan Muhammad Idrus Kaimuddin merupakan pendiri awal Zawiyah di kesultanan Buton. Menyusul kemudian H. Abdul Ganiu, dan anak-anaknya yaitu Muhammad Nuh dan Sultan Muhammad Idrus Kaimuddin. Sebagaimana yang dikatakan oleh Imran Kudus bahwa:

Zawiyah didirikan untuk pertama kali oleh Sultan Muhammad Idrus Kaimuddin, kemudian Haji Abdul Ganiu. Setelah itu Muhammad Nuh anak dari sultan Muhammad Idrus Kaimuddin, dan terkahir Sultan Muhammad Umar. Muhammad Nuh adalah anak dari Sultan Muhammad Idrus Kaimuddin, dan Sultan Muhammad Umar adalah cucu dari H. Abdul Ganiu, dan Sultan Muhammad Idrus Kaimuddin. Ayah Sultan Muhammad Umar adalah anak dari H. Abdul Ganiu dan Ibu Sultan Muhammad Umar adalah anak dari Sultan Muhammad Idrus Kaimuddin. ${ }^{27}$

Lokasi keberadaan masing-masing Zawiyah tersebut berbeda-beda. Zawiyah Muhammad Idrus Kaimuddin terletak di dalam Benteng Badia sebelah barat, sementara Zawiyah H. Abdul Ganiu di pemakaman Baria sebelah selatan dari arah keraton Buton yang sekarang. Sedangkan Zawiyah Muhammad Nuh terletak di Daerah Wajo Kecamatan Murhum kota Baubau, tepatnya di Tanah Mandala atau Tanah Weta (suatu lokasi yang sering disebut oleh masyarakat setempat). Zawiyah Sultan Muhammad Umar, terletak di Kamali Bata di wilayah

\footnotetext{
${ }^{25}$ A. Mulku Zahari, sejarah dan Adat fì dār al-Butūnī jilid I, II dan III (Jakarata: Departemen Pendidikan dan Kebudayaan, 1977), h. 28.

${ }^{26}$ Abd. Rahim Yunus, Posisi Tasawuf dalam Sistem Kekuasaan di Kesultanan Buton pada Abad ke-19, h. 75 dan 77. 2018.

${ }^{27}$ Imran Kudus, Sejarawan dan Budayawan Buton, Wawancara, Baubau, Tanggal 23 Juni
} 
keraton Buton sekarang. ${ }^{28}$ Keempat Zawiyah ini, masih dapat diidentifikasi jejakjejak bangunannya sampai sekarang. Hanya saja, bangunannya tidak seutuh pada masanya, bahkan sudah menjadi puing-puing reruntuhan, kecuali Zawiyah $\mathrm{H}$. Abdul Ganiu, bangunannya masih berdiri kokoh sampai dengan penelitian ini dilakukan. Terkait hal itu Imran Kudus selanjutnya mengatakan:

Ada empat Zawiyah pada masa kesultanan Buton, tiga masih ditemukan bekas-bekasnya, satu masih dalam keadaan yang bagus, dua tinggal puingpuingnya dan satu tidak ditemukan lagi jejaknya. ${ }^{29}$

Berdasarkan hal itu, maka Zawiyah pada masa kesultanan Buton, merupakan institusi pendidikan Islam yang tidak terikat dangan sistem hirarki dalam kekuasaan pemerintahan kesultanan Buton. Sebaliknya Zawiyah memberikan kontribusi secara tidak langsung dalam penyebaran ajaran Islam di kesultanan Buton, khususnya pemahaman tasawuf dan ajaran fikih yang kemudian memberi pengaruh terhadap hukum-hukum pemerintahan kesultanan Buton. Seperti martabat tujuh, falsafah pobinci-binci kuli yang keseluruhannya memuat nilai-nilai ajaran Islam. Bahkan memberi pengaruh terhadap penegakan syariat Islam pada pemerintahan Kesultanan Buton. LM Kariu mengatakan "bahwa pada masa Kesultanan Buton pemerintahannya menjalankan syariat Islam".30 Hal serupa juga dikatakan oleh LM Anshari Idris, bahwa wajib hukumnya bagi lakilaki Muslim shalat lima waktu di Masjid". ${ }^{31}$ Oleh karena itulah, pada masa pemerintahan kesultanan Buton, khususnya di masa Sultan Muhammad Idrus Kaimuddin negeri ini dikenal juga dengan negeri khalīfah al-khämis (khalifah kelima setelah para sahabat), disebabkan ketaatan masyarakat dan pemerintahannya menjalankan syariat Islam.

\section{B. Pelaksanaan Pendidikan Islam di Zawiyah pada Masa Kesultanan Buton}

1. Materi pembelajaran

Zawiyah pada masa kesultanan Buton merupakan pusat pembelajaran pendidikan Islam, pada awalnya sebagai tempat pembelajaran ilmu tasawuf kemudian berkembang menjadi pembelajaran, agama, sastra dan pemerintahan. Agama mencakup akidah dan syariat di antara materinya adalah tasawuf, ușūl dan

\footnotetext{
${ }^{28}$ Imran Kudus, Sejarawan dan Budayawan Buton, Wawancara, Baubau, Tanggal 23 Juni 2018.

${ }^{29}$ Imran Kudus, Sejarawan dan Budayawan Buton, Wawancara, Baubau, Tanggal 23 Juni 2018.

${ }^{30}$ La Ode Muhammad Kariu, Tokoh Agama dan Budayawan Buton, Wawancara, Baubau Tanggal 28 Juni 2018 .

${ }^{31}$ La Ode Muhammad Anshari Idris, Tokoh agama dan Budayawan Buton, Wawancara, Baubau 26 Juni 2018.
} 
fikih serta ilmu hakekat, ibadah dan akhlak. Sementara sastra mencakup bahasa dan budaya. Sedangkan ilmu pemerintahan meliputi norma adat dan hukum Islam. Terkait hal itu LM Anshari Idris dan LM Kariu serta Imran Kudus menyatakan bahwa:

Materi pembelajaran Zawiyah sangat beragam tidak hanya ilmu tasawuf saja yang diajarkan, melainkan juga ilmu fikih, ibadah dan akhlak, seperti pembahasan tentang țahara, bacaan al-Qur'ān mulai dari ilmu tajwid, sampai kepada bentuk lagunya. Kadang-kadang juga norma kesusilaan yang berkaitan dengan sistem pemerintahan kesultanan Buton. ${ }^{32}$

Tradisi pembelajaran fikih di Zawiyah berkembang pesat setelah masa pemerintahan Sultan Muhammad Umar, meskipun sebelumnya tradisi pembelajaran tersebut telah diajarkan di Zawiyah, mulai dari masa Sultan Muhammad Idrus Kaimuddin sampai kepada masa Sultan Muhammad Umar, namun tradisi pembelajaran fikih lebih menonjol dibandingkan tradisi tasawuf. Hal ini untuk memurnikan paham-paham yang berkembang pada masyarakat Buton yang lebih mengutamakan aspek batin dibandingkan aspek lahirnya. Terkait dengan itu Imran Kudus menyebutkan bahwa:

Kira-kira sepeninggal Sultan Muhammad Umar, fikih itu mulai diajarkan di Zawiyah atau sebelumnya, tapi yang jelas sepeninggal Sultan Muhammad Umar itu, pembelajaran fikih itu sudah ada. ${ }^{33}$

Perkembangan tradisi pembelajaran tasawuf dan fikih di Zawiyah, telah mewarnai sejumlah pemikiran tentang konsep makrifat dan hakekat dalam kesultanan Buton. Aspek yang paling menonjol adalah pada pemaknaan konsep fana' dan baqa', zikir, khalwat, murāqabah, maqāmat dan wahdah al-wujūd yang menjadi inti pembelajaran tasawuf di Zawiyah. Tetapi tidak menjadi pertentangan antara ajaran tasawuf dan fikih di kesultanan Buton, seperti yang terjadi di daerahdaerah lain di nusantara (sebutan Indonesia dulu). Hal itu ditandai dengan perhatian masyarakatnya pada pelaksanaan perbuatan lahiriyah, seperti șalat, puasa, zakat, dan haji, sebagaimana yang terungkap dalam tulisan sultan Muhammad Idrus Kaimuddin yang dikutip oleh Rahim Yunus bahwa "nikmat yang paling tinggi adalah saat melihat Tuhan dalam musyāhadah. Tetapi itu dapat

\footnotetext{
${ }^{32}$ Imran Kudus, LM Kariu, La Ode Muhammad Anshari Idris, Sejarawan Tokoh Agama dan Budayawan Buton, Wawancara, Baubau, Tanggal 23, 26 dan 28 Juni 2018.

${ }^{33}$ Imran Kudus, Sejarawan dan Budayawan Buton, Wawancara, Baubau, Tanggal 23 Juni 2018.
} 
dicapai setelah segala perintah Tuhan, seperti shalat, puasa, dan zakat dilaksanakan dan segala larangannya ditinggalkan". ${ }^{34}$

Ajaran-ajaran tasawuf dan fikih dikembangkan dan dipadukan di dalam Zawiyah. Fikih diajarkan di Zawiyah, sebagai fondasi awal untuk memasuki ajaran tasawuf, dan tasawuf menjadi jembatan untuk memasuki kedalaman inti ilmu hakekat atau dalam istilah para pendiri Zawiyah disebut dengan ilmu rahasia yang hanya dimililki oleh orang-orang tertentu. H. Abdul Ganiu dalam La Niampe menyatakan ada tiga macam ilmu yang harus dipelajari oleh seorang murid, yaitu ilmu uṣūl dan fikih, ilmu tasawuf, dan ilmu hakekat atau ilmu rahasia. ${ }^{35}$ Berkenaan dengan ilmu rahasia H. Abdul Ganiu melantunkan dalam syairnya ajonga inda malusa yang dikutip oleh La Niampe.

Ataluaka ilmu rahasia

Ositumu ompolena imatau

Asarongia lolina hakikati

Rahasiana sabara kawuni-wuni

Ositumo ilimu aharamu itulah

Bea rangoa mia sumbauaka

Kapaka katau incia itu sebab

Rahasiana opu ibuniakana ${ }^{36}$
Yang ketiga ilmu rahasia

Itulah bijinya ilmu

Dinamakan isinya hakekat

Rahasia segala yang tersembunyi

Ilmu yang diharamkan

Didengar orang seperti aku

Karena pengetahuan yang seperti itu

Rahasia Tuhan yang disembunyikan

Pernyataan yang sama juga diungkapkan oleh Sultan Muhammad Idrus Kaimuddin dalam syairnya:

Neu peelu bicarana tasaofu

Ngaji kea paramata molabina

Ikarangina sulutani aalimu

Hadamuana fakiri tee miskini

Podo saide boli upatelaia

Tabeanamo laengana morangoa

Osaaliki obawine oumane

Tee aalimu ee malingu saleh
Kalau ingin ajaran tasawuf

Baca paramata molabina (jauhara manikam)

Yang dikarang oleh sultan yang alim Keadaannya fakir dan miskin

Namun sedikit jangan jadikan umum Kecuali yang pantas mendengar Sālik perempuan dan laki-laki Dengan alim dan segala orang saleh $^{37}$

\footnotetext{
${ }^{34}$ Abd. Rahim Yunus, Posisi Tasawuf dalam Sistem Kekuasaan di Kesultanan Buton pada Abad ke-19, h. 100.

${ }^{35}$ La Niampe, Syair Ajonga Inda Malusa: Pengantar dan Suntingan Naskah, h. 112.

${ }^{36}$ La Niampe, Syair Ajonga Inda Malusa: Pengantar dan Suntingan Naskah, h. 116.

37، Aidrus, Tazikri, dalam SBF: 213 ditranskrip dan diindonesiakan oleh A. Mulku Zahari bekerjasama dengan KITLV Jakarta (Baubau: stensilan, 1985, h. 31-2. Dalam Abd. Rahim Yunus, Posisi Tasawuf dalam Sistem Kekuasaan di Kesultanan Buton pada Abad ke-19, h. 102.
} 
Menurut kedua tokoh tersebut, bahwa ajaran tasawuf, baik tarekat maupun teosofi bukan untuk diajarkan pada orang kebanyakan. Dalam artian mereka membedakan mana yang boleh dan tidak boleh menerima ajaran ini. Pada perspektif ini terjadi pemahaman yang beragam dikalangan masyarakat Buton. Diantaranya ada yang menganggap bahwa ajaran tersebut hanya dapat diperuntukan oleh orang-orang yang ada di wilayah Keraton Kesultanan Buton, karena Zawiyah berada di dalamnya, sehingga golongan papara di Kadie yang berada di luar Keraton tidak berkenan untuk mendapatkan ilmu ini. Sebagaian juga ada yang menganggap bahwa pernyataan yang layak dan tidak layak mendapatkan ilmu tasawuf dalam syair tersebut, bukan antara orang luar dan orang dalam di wilayah Keraton melainkan orang-orang yang terpilih dalam proses pembelajaran di Zawiyah. Sehingga terkesan Zawiyah pada masa itu sangat bersifat eksklusif dalam pembelajarannya. Berkenaan dengan hal itu LM Anshari Idris dan LM Kariu mengatakan bahwa "untuk mempelajari ilmu tasawuf yang ada di Zawiyah harus berumur 40 tahun, telah lulus ilmu fikih dan dipilih langsung oleh mursyidnya"38

Pernyataan ini pula didukung oleh teks Kabanti Ajonga Inda Malusa karya H. Abdul Ganiu yang mengisyaratkan bahwa yang layak untuk mendapatkan kebaikan hidup di dunai dan kemuliaan di akhirat adalah mereka yang beriman. persepsi orang beriman dalam kabantinya adalah mukmin, baik itu seorang bangsawan, maupun seorang hamba sahaya atau budak. Bangsawan dalam pemerintahan Kesultanan Buton adalah kaumu dan walaka sementara masyarakat biasa adalah papara dan budak adalah batua. ${ }^{39}$

Oilimu barangkala mincuana

Santaongana laengana morangoa

Mao kawasa tawa olakina lipu Ilmu kalau bukan Pantasnya wajar yang didengar Walaupun yang berkuasa, kaya dan raja negeri

Hengga kawana anana nemincuana Walaupun sampai pada anaknya kalau bukan

Olaengana morangoa amendu

Adaria baranco soa binasa

Nebarangkala mia itu alaenga

Bea rangoa katau incia itu

Ma batua fakiri kasi asi walaupun
Yang pantas mendengar tidak mau Mengajarkan jangan sampai binasa Kalau orang itu wajar Untuk mengajarkan ilmu itu. Budak fakir hina

${ }^{38} \mathrm{LM}$ Anshari Idris dan LM Kariu, tokoh agama dan tokoh Budaya Buton, wawancara, baubau, 25 dan 26 Juni 2018.

${ }^{39}$ Abd. Rahim Yunus, Posisi Tasawuf dalam Sistem Kekuasaan di Kesultanan Buton pada Abad ke-19, h. 24-25. 


$\begin{array}{ll}\text { Adaria kawana aponamboa } & \text { Diajarnya sampai diupahnya } \\ \text { Tuamo itu saro alimu mpu } & \text { Demikian itu disebut alim betul } \\ \text { Amangadari inda tei belokina }{ }^{40} & \begin{array}{l}\text { Mengajar kita tanpa sesuatu yang } \\ \text { diharapkan }\end{array}\end{array}$

Berdasarkan pernyataan tersebut, maka materi-materi pembelajaran di Zawiyah pada masa kesultanan Buton dibagi kedalam dua unsur, yakni tasawuf dan fikih. Tasawuf menyangkut tarekat dan teosofi, sedangkan fikih menyangkut ibadah mahdah dan muamalah, termasuk didalamnya ilmu sastra dan pemerintahan.

2. Metode pembelajaran di Zawiyah

Sistem pembelajaran di Zawiyah bertitik tolak pada figur seorang mursyid dalam memberikan materi-materi pendidikan Islam kepada murid-muridnya. Materi yang diajarkan disesuaikan dengan kondisi muridnya. Hanya saja pemberian materi tidak bersifat sistematik seperti penggunaan kurikulum dalam sistem pendidikan modern saat ini. oleh karena ketersediaan sarana dan prasarana yang tidak mencukupi untuk dilakukan proses pembelajaran yang lebih lanjut. Akibatnya murid-murid di Zawiyah hanya dapat mengikuti proses pembelajaran, bila ada jadwal yang telah ditentukan oleh mursyidnya terkait hal itu. Al-Mujazi menyebutkan bahwa "murid-murid di Zawiyah dapat mengikuti proses pembelajaran, bila ada jadwal yang telah ditentukan oleh mursyidnya". ${ }^{4}$ Dikatakan juga oleh LM Anshari Idris bahwa "di dalam Zawiyah digunakan jadwal pembelajaran untuk materi apa yang mesti diajarkan pada murid-muridnya sesuai dengan kesepakatan bersama". ${ }^{42}$

Kegiatan pembelajaran di Zawiyah bersifat sentralistik, hal ini ditunjukan dengan keberadaan mursyid sebagai panutan yang mesti diikuti oleh muridmuridnya, namun hal itu tidak mejadikan murid-muridnya kurang kritis terhadap materi yang diajarkan. Terdapat metode-motede pembelajaran yang ada di Zawiyah.

Metode tersebut biasanya disesuaikan dengan materi pemebelajaran yang ada. Di antara metode-metode tersebut adalah metode ceramah, tanya jawab dan sorogan, maupun halaqah. Hal ini disampaikan oleh LM Kariu bahwa:

Biasanya penggunaan metode pembelajaran seperti tanya jawab, ceramah, sorogan dan juga halaqah di dalam Zawiyah berhubungan dengan materi

\footnotetext{
${ }^{40}$ La Niampe, Syair Ajonga Inda Malusa: Pengantar dan Suntingan Naskah, h. 110-111.

${ }^{41}$ Al-Mujazi Mulku Zahari, Tokoh Budaya, dan Penjaga Naskah serta Museum Kesultanan Buton, Wawancara, Baubau tanggal 24 Juni 2018.

${ }^{42}$ LM Anshari Idris, Tokoh Agama dan Budaya Buton, Wawancara, Baubau tanggal 26 Juni 2018.
} 
fikih, bacaan al-Qur'ān dan materi-materi lain yang menyangkut ibadah dan muamalah. Adapun materi-materi tasawuf menggunakan metode tertentu yang hanya diperkenankan oleh mursyidnya. ${ }^{43}$

Penggunaan metode yang disesuaikan dengan materi pembelajaran yang ada, disebabkan murid-murid yang ada di Zawiyah tidak hanya di kalangan orang tua saja, laki-laki, kalaupun perempuan, tetapi juga di kalangan remaja dan anakanak. Hal ini dipersiapkan agar anak-anak dan remaja, dikemudian hari dapat mempelajari ilmu tasawuf yang hanya diperkenankan bila usianya mencapai umur 40 (empat puluh) tahun. Bagi anak-anak dan remaja, diperuntukan belajar fikih, baca tulis al-Qur'ān, mulai dari ilmu tajwid sampai kepada bentuk lagunya. Adapun kalangan dewasa dan orang tua yang telah mencapai usia 40 (empat puluh) tahun diperkenankan belajar ilmu tasawuf, bila mendapatkan rekomendasi dari mursyidnya. ${ }^{44}$

Metode yang digunakan dalam pembelajaran tasawuf di Zawiyah adalah metode suluk. Di dalam suluk, murid-murid yang telah diperkenankan oleh mursyidnya di tempatkan dalam ruangan khusus di rumah-rumah masyarakat dan disiapkan ruangan yang dikenal dengan istilah sogi bagi masyarakat Buton. Sogi adalah ruangan kecil berukuran hanya satu orang saja. Sebagian ada juga yang di tempatkan di Zawiyah, seperti yang dilakukan oleh Sultan Muhammad Idrus Kaimuddin, yang menempatkan muridnya di Zawiyah bila telah memenuhi syarat belajar tasawuf. $^{45}$

Murid yang disuluk mendapat perhatian khusus dari mursyidnya, diberikan arahan dan bimbingan langsung untuk mendapatkan tingkatan atau maqāmat dalam ilmu tasawuf. Murid-murid dapat menjalankan proses suluk itu sesuai dengan kemampuannya dalam memahami dan mengungkap misteri kegaiban sang Maha gaib. Proses tersebut bisa berjalan satu, dua atau tiga hari, bahkan sampai 40 (empat puluh) hari tergantung kemampuan murid tersebut melalui bimbingan mursyidnya. Terkait hal itu LM Anshari mengatakan:

Murid yang mendapatkan suluk disiapkan ruang yang khusus berupa kelambu, dan disiapkan juga makan dan minuman yang dibutuhkan. Murid hanya menjali proses suluk, dengan materi zikir yang diberikan oleh mursyidnya. Proses suluk dapat berjalan satu, dua atau tiga hari, bahkan empat puluh hari, tergantung kemapuan murid tersebut saat disuluk, tetapi Juni 2018.

${ }^{43}$ LM Kariu, Tokoh agama dan Dosen STAI Baubau, Wawancara, Baubau, Tanggal 28

${ }^{44}$ LM Kariu, Tokoh agama dan Dosen STAI Baubau, Wawancara, Baubau, Tanggal 28 Juni 2018.

${ }^{45}$ Imran Kudus, sejarawan dan Budayawan Buton serta Dosen di Universitas Muhammadiyah Buton, Wawancara, Baubau, Tanggal 23 Juni 2018. 
bukan berarti bahwa setelah disuluk dia telah lulus belajar ilmu tasawuf. Hal itu hanya bisa ditentukan oleh mursyidnya sendiri. ${ }^{46}$

Berkenaan dengan hal itu dikatakan juga oleh Imran Kudus bahwa:

Dalam rangka mensucikan jiwa, maka murid-murid di Zawiyah mendapatkan suluk, sebagian ditempatkan di dibawah kolong Zawiyah yang dibangun untuk proses suluk, sebagian juga ditempatkan di rumahrumah disiapkan ruangan khusus atau sogi untuk bersuluk satu, dua, atau tiga hari, diberikan makan sedikit, dan disuruh berzikir oleh mursyidnya. bagi murid yang menjalani proses tarekat itu. ${ }^{47}$

Berdasarkan pernyataan tersebut, bahwa metode pembelajaran di Zawiyah sangat beragam disesuaikan dengan materi pembelajaran yang ada. Di samping motede pembelajaranya bersifat sentralistik dimana mursyid sebagai figur utama dalam melakukan proses pembelajaran, terdapat juga motede tanya jawab dan sorogan yang diperkenankan atas izin mursyidnya.

Pengusaan materi pembelajaran oleh murid dapat dinyatakan lulus, atau menuju tingkat pembelajaran selanjutnya, ditentukan oleh mursyid, tanpa melalui proses evaluasi atau penilaian secara kognitif layaknya dalam lembaga-lembaga pendidikan Islam modern saat ini. Hal ini disebabkan karena pendalaman materi tasawuf sebagai pijakan untuk menguji keabsahan materi-materi lain seperti fikih hanya ditentukan oleh penglihatan dan pengamatan mursyidnya. Selain itu juga, tidak setiap murid yang ada di Zawiyah dapat menerima pelajaran ilmu tasawuf, jika bukan atas ketentuan mursyidnya.

3. Hubungan antara mursyid dan murid dalam Zawiyah

Sepanjang pola pembalajaran di Zawiyah sikap dan disiplin ilmu yang dipelajari oleh mursyidnya ditransformasikan secara langsung kepada muridmuridnya dalam berbagai macam bentuk metode pembelajaran. Terdapat juga kiat-kiat khusus untuk merangsang dan memotivasi murid-muridnya agar semangat belajar. Tetapi kiat-kiat tersebut juga dapat diperkenankan jika muridnya memiliki keinganan dan keyakinan untuk mendengarkan dan mengikuti ajaran yang diberikan kepadanya. Dalam hal ini murid harus selalu hormat kepada gurunya, memiliki disiplin pada saat pembelajaran berlangsung. Berkenaan dengan itu LM Anshari Idris berkata bahwa:

\footnotetext{
${ }^{46}$ LM Anshari Idris, Tokoh Agama dan Budaya Buton, Wawancara, Baubau tanggal 26 Juni 2018.

${ }^{47}$ Imran Kudus, Sejarawan dan Budayawan Buton serta Dosen di Universitas Muhammadiyah Buton, Wawancara, Baubau, Tanggal 23 Juni 2018.
} 
Tanggung jawab seorang mursyid kepada muridnya jauh labih besar dibandingkan tanggung jawab murid kepada mursyidnya, karena yang diajarkan tidak hanya ilmu dunia, tetapi ilmu akhirat, sehingga murid itu harus selalu hormat kepada mursyidnya". ${ }^{48}$

Selain pendiri Zawiyah sebagai mursyid satu-satunya, terdapat juga mursyid lain yang mengajar di Zawiyah tersebut. Mursyid itu bisa juga dari Zawiyah yang lain yang ada di wilayah Keraton dan bisa juga didatangkan dari luar wilayah kekuasaan pemerintahan kesultanan Buton. Hal ini dapat dicermati dari ungkapan Imran Kudus bahwa:

Pada masa sultan Muhammad Idrus Kaimuddin dia guru satu-satunya di lembaganya itu, tapi, di lembaga yang lain di Zawiyah $\mathrm{H}$ Abdul Ganiu dia juga guru, begitu juga sebaliknya, karena keduanya hidup pada zaman yang sama, di dalam riwayat lokal dicertiakan pula dia mendatangkan 40 said bergantian, said ini dari mana saja mungkin dari Hadramaut, atau dari Arab Timur Tengah lain, dalam tradisi lokalnya dia kebagian 40 said, atau guru bantu dari luar daerah gantian terus setiap tahun 40 orang, memang dari riwayat lokalnya diceritakan begitu, sampai yang terkahir datang gurunya itu, syekh Muhammad Sumbul al-Makki, orang Buton menyebutnya Syekh Mancuana, karean dia datang itu sudah usianya sangat sepuh ${ }^{49}$

Selain itu juga, LM Anshari Idris, menyebutkan bahwa "mursyid yang ada di Zawiyah dapat juga dari kalangan murid yang sudah tamat dan diberi kuasa mengajar untuk bidang yang memang dikuasainya dan ditunjuk langsung oleh mursyidnya dalam hal ini pendirinya". 50 Selanjutnya, LM Anshari Idris menambahkan, bagaimana hubungan antara murid kepada mursyidnya dalam ungkapannya sebagai berikut:

Etika antara murid kepada mursyidnya disitu akhlak yang menentukan. Artinya tetap penghormatannya kepada mursyidnya, berkenaan dengan disiplin hanya ada pada kesepakatan jam pembelajaran saja, selesai jamnya selesai juga kajian. Kemudian kewajiban murid kepada mursyidnya, memperhatikan kebutuhan mursyidnya, seperti,

${ }^{48}$ LM Anshari Idris, Tokoh Agama dan Budaya Buton, Wawancara, Baubau, Tanggal 26 Juni 2018.

${ }^{49}$ Imran Kudus, Sejarawan dan Budayawan Buton, Wawancara, Baubau 23, 28 Juni 2018.

${ }^{50}$ LM Anshari Idris, Tokoh Agama dan Budaya Buton, Wawancara, Baubau, Tanggal 26 Juni 2018. 
mengambilkan atau menyadiakan air untuk gurunya, kayunya bagi segala kebutuhannya itu, dibawakan saja oleh muridnya. ${ }^{51}$

Merujuk dari pernyataan tersebut, maka dapat dilihat bahwa usaha yang dilakukan oleh para pendiri Zawiyah dalam meningkatkan kualitas pembelajaran dengan mendatangkan para sā'id (guru bantu) dan juga penunjukan dari beberapa murid yang memiliki kualitas pembelajaran yang baik, merupakan bagian yang tidak terpisahkan dalam membangun hubungan emosional dan spirit pembelajaran bagi murid-muridnya untuk selalu aktif di dalam menuntut ilmu di Zawiyah. Namun, hubungan mursyid dan murid tidak bisa hanya dilihat melalui aspek lahiriyah yang tergambar dalam bentuk adab, etika, kesopanan dan penghormatan kepada mursyidnya saja, melainkan hubungan tersebut diwujudkan dalam lautan kedalaman batin antara hamba dengan tuannya, antara mukmin dengan 'ālim dan antara hamba dengan Tuhannya. Jika ditelusuri hubungan antara murid dan mursyid dalam Zawiyah dapat dijumpai dalam karya-karya yang ditulis oleh pendirinya. Salah satu cakupan yang membahas tentang hubungan mursyid dan murid terdapat dalam Kabanti Ajonga Inda Malusa karya H. Abdul Ganiu, dalam penggalan syair yang dikutip oleh La Niampe dia berkata:
Mincuanapo isarongi alimu
Belum dinamakan orang alim
Nesabutuna adari mea rangana
Kalau hanya mengajar orang sesama
Tabeanamo asarongi alimu
Apolimo taedari karona ${ }^{52}$
Kecuali yang dinamakan alim
Sudah dapat mengajar dirinya

Pengagalan syair tersebut, mengisyaratkan bagaimana kedalaman spritual yang dimiliki oleh seorang mursyid untuk dipatrikan kedalam jiwa muridnya, karena hanya dengan sentuhan spritual hubungan antara mursyid dan murid dapat dirasakan, layaknya seperti merasa diri sendiri. Oleh karena itu, dalam proses pembelajaran di Zawiyah, tasawuf merupakan sarana sekaligus media pembelajaran bagi murid di Zawiyah untuk menjalin hubungan spiritual di antara mereka.

Berdasarkan pandangan tersebut, maka hubungan antara mursyid dan murid di dalam Zawiyah diaplikasikan pada saat proses pembelajaran berlangsung, khususnya pada materi tasawuf, yang merupakan jembatan perjumpaan, bukan saja antara murid dan mursyidnya, melainkan juga antara murid, mursyid dan Tuhannya. Dan inilah jembatan tranformasi keilmuan dalam Zawiyah pada masa kesultanan Buton.

\footnotetext{
${ }^{51}$ LM Anshari Idris, Tokoh Agama dan Budaya Buton, Wawancara, Baubau, Tanggal 26 Juni 2018.

${ }^{52}$ La Niampe, Syair Ajonga Inda Malusa: Pengantar dan Suntingan Naskah, h. 129.
} 
Kurikulum yang dipakai dalam dunia tasawuf memang berorientasi untuk menjadikan peserta didik sebagai calon-calon sufi, melalui pembersihan diri dengan jalan maqāmat yang telah ditentukan oleh seorang mursyid atau syaikh. Hal ini mungkin sulit untuk diterapkan dalam dunia pendidikan modern saat ini, mengingat metode yang digunakannya bersifat intuisi melalui jalur kebatinan yang berbeda arah dengan pendidikan modern dengan metode pengetahuan yang bersifat lahiriyah. Namun, bukan berarti dimensi iman, ilmu dan amal ditinggalkan hanya karena perbedaan metode. Bukankah inti dari metode adalah guru, dan ruh atau sprit guru tersebut dapat membawa murid (peserta didik) ke jalan ma'rifat Allah.

\section{Peran Zawiyah terhadap Perkembangan Pendidikan Islam di Buton}

Penggunaan istilah Zawiyah sebagai institusi pendidikan Islam pada masa Kesultanan Buton sesungguhnya diadopsi dari sistem pembelajaran sufisme yang menerangkan kegiatan pembelajaran berada di pojok-pojok masjid, bertafakur, melakukan zikir sebagai bentuk pengejewantahan makna spritualisme hamba kepada Tuhan-Nya, dan juga merupakan tempat sekelompok orang berkumpul untuk mendengarkan pengajaran seorang syaikh. ${ }^{53}$ Istilah ini kemudian digunakan pada masa Kesultanan Buton di abad ke-19 (kesembilan belas) untuk menunjukkan kegiatan yang sama dengan sufisme, hanya saja Zawiyah di Buton identik dengan sebuah bangunan tempat bertemunya murid dan mursyid, melakukan percakapan ilmu tasawuf dan fikih, ${ }^{54}$ membahas antara tersirat dan tersurat yang dikemudian hari dikenal dengan ilmu rahasia atau ilmu hakekat ${ }^{55}$ suatu prespektif ontologis mengungkap tabir kemisteriusan sang Maha Misterium.

Zawiyah pada masa Kesultanan Buton memadukan dua unsur pembelajaran, yaitu ajaran tasawuf dan ajaran fikih, kemudian ditransformasikan ke dalam tiga bahasa, yakni bahasa Arab, Melayu dan Wolio (bahasa Buton). ${ }^{56}$ Proses transformasi ke dalam bahasa Wolio lebih dominan dibandingkan dengan dua bahasa tersebut. Menurut LM Anshari Idris pengunaan bahasa Wolio adalah salah satu aspek dalam memahamkan ajaran Islam kepada masyarakat, lebih lanjut ia menyebutkan bahwa:

Sebagian masyarakat bahkan sebagian muridnya juga seperti merasa jenuh dengan bahasa Melayu, maka didirikanlah Zawiyah, hanya untuk

\footnotetext{
${ }^{53}$ Maqrizi, "Mawa'id II", h. 429, dalam Hasan Asari, Menyingkap Keemasan Islam: Kajian atas Lembaga-lembaga Pendidikan Islam (Jakarta: Mizan, 1994), h. 96.

${ }^{54}$ Imran Kudus, Sejarawan dan Dosen di Universitas Muhammadiyah Buton, Wawancara, Baubau, Tanggal 23 Juni 2018.

${ }^{55}$ La Niampe, Syair Ajonga Inda Malusa: Pengantar dan Suntingan Naskah, h. 116.

${ }^{56}$ Al-Mujazi Mulku Zahari, Tokoh Budayawan Buton, Wawancara, Baubau, tanggal 24 Juni 2018
} 
memahamkan ajaran Islam dengan bahasa dan tulisan Buton, tidak lagi dalam bahasa Melayu. ${ }^{57}$

Usaha memadukan dua unsur pembelajaran tasawuf dan fikih di Zawiyah, sesungguhnya memperkuat fondasi pemerintahan Kesultanan Buton itu sendiri, dan juga memurnikan ajaran-ajaran yang menyimpang dari syariat Islam. Di dalam riwayat dikatakan, bahwa pada masa Muhammad Idrus Kaimuddin menjadi sultan, pernah menjatuhkan hukuman mati kepada seseorang yang diketahui tidak melakukan shalat. ${ }^{58}$

Ajaran-ajaran tasawuf dan fikih di Zawiyah berkembang pesat pada pemerintahan kesultanan Buton, namun keberadaan Zawiyah sendiri, hanya dapat dinikmati oleh kalangan di wilayah Keraton Buton. Sehingga timbullah pemahaman sebagian dikalangan masyarakat Buton, bahwa ilmu tasawuf di Zawiyah, hanya diperuntukan bagi kalangan di dalam wilayah keraton dalam hal ini para bangsawan keturunan kaumu dan walaka, bukan untuk kalangan luar yaitu papara dan batua di kadie.

Sejalan dengan sumber pada abad ke-19 yang diteliti oleh Abd. Rahim Yunus di beberapa tempat bekas wilaya kadie, yaitu Wanci, Pasar Wajo, Lasalimu, dan Kabaena menunjukan bahwa tidak dikenal adanya bekas Zawiyah di daerah bekas kadie tersebut, dan tidak dijumpai pula orang biasa (papara dan batua) memiliki ajaran-ajaran tasawuf baik yang lisan maupun tertulis yang ditinggalkan oleh pendahulu-pendahulu mereka pada masa kesultanan. Bekas Zawiyah hanya ada pada pusat kesultanan, dan naskah-naskah peninggalan ajaran tasawuf hanya ditemukan pada keturunan kaumu dan walaka. Hal ini menunjukan bahwa pengajaran tasawuf pada masa kesultanan Buton hanya berlaku khusus bagi kalangan kaumu dan walaka di Keraton, tidak bagi kalangan papara dan batua di kadie. ${ }^{59}$ Oleh karena itulah, maka timbul pemahaman bahwa Zawiyah sebagai pendidikan Islam pada masa kesultanan Buton cenderung bersifat eksklusive.

Zawiyah dalam perkembangannya kemudian mengalami kemunduran sejak ditinggalkan oleh para pendirinya pada akhir abad ke-19 (kesembilan belas). Tidak ada lagi institusi-institusi pendidikan Islam seperti Zawiyah yang diterapkan di Buton sampai saat ini. Imran Kudus dkk menyebutkan bahwa

\footnotetext{
${ }^{57}$ LM Anshari Idris, Tokoh Agama dan Budayawan Buton, Wawancara, Baubau, Tanggal 26 Juni 2018.

${ }^{58}$ Abdul Mulku Zahari, "Sejarah Masuknya Islam di Buton dan Perkembangannya" Makalah Disampaikan dalam Seminar Sejarah Masuknya Islam di Buton yang Diadakan oleh Fakultas Tarbiyah, IAIN Aluaddin Baubau pada Tanggal 1 Maret (1990), h. 122.

${ }^{59}$ Abd. Rahim Yunus, Posisi Tasawuf dalam Sistem Kekuasaan di Kesultanan Buton Pada Abad Ke-19, h. 102.
} 
"sampai saat ini, belum ada Zawiyah di Buton selain dari Zawiyah pada masa itu, hanya bekas ajarannya yang dapat disinyalir sebagai ajaran yang ada di Zawiyah". ${ }^{60}$ Jika dikaji secara mendalam terhentinya keilmuan pasca pendiripendiri Zawiyah, selain tidak adanya pengkaderan yang sistematis dari para ulama pendahulu, juga disebabkan karena adanya pola penyebaran Islam pada masamasa awal yang bersifat struktural. ${ }^{61}$ Hal inilah yang membuat mengapa Zawiyah kurang membumi di separuh abad ke-20 (kedua Puluh).

Berdasarkan pandangan tersebut, maka dapat disimpulkan bahwa pendidikan Islam di Zawiyah pada masa kesultanan Buton abad ke-19 (kesembilan belas) merupakan bagian dari proses Islamisasi antara Islam dan budaya lokal yang diintegrasikan dalam proses pembelajaran di Zawiyah menggunakan kurikulum sufi dan diadaptasikan dengan tradisi setempat melaui penggunaan bahasa Arab, Melayu dan Wolio (bahasa Buton). Proses Islamisasi inilah yang kemudian mendapat tempat di hati masyarakat Buton, meskipun pelaksanaan pendidikannya masih bersifat eksklusive hanya terbatas pada masyarakat keraton saja, namun telah memberi inspirasi bagi perkembangan pendidikan Islam selanjutnya, melalui putra-putra Buton yang datang dari Timur Tengah memberikan pencerahan keislamam bagi masyarakat Buton secara menyeluruh tanpa terkecuali.

\section{PENUTUP}

\section{A. Kesimpulan}

Zawiyah sebagai institusi pendidikan Islam pada masa kesultanan Buton merupakan hasil adaptasi antara ajaran Islam dan tradisi masyarakat lokal dicirikan dengan bangunan tempat bersemayamnya murid dan mursyid melakukan pembelajaran agama Islam dalam bidang tasawuf dan fikih. Didirikan pada awal abad ke-19 (kesembilan belas) di masa pemerintahan sultan Muhammad Idrus Kaimuddin sampai masa sultan Muhammad Umar (1824/1851-1885/1906 M). Terdapat empat Zawiyah pada masa kesultanan Buton, dibangun sesuai dengan nama pendirinya, yaitu Zawiyah sultan Muhammad Idrus Kaimuddin, Zawiyah $\mathrm{H}$. Abdul Ganiu (Kenepulu Bula) Zawiyah Muhammad Nuh (Kanepulu Bente) dan Zawiyah sultan Muhammad Umar (1885-1906 M). 28 Juni 2018

${ }^{60}$ Imran Kudus, dkk, Sejarawan dan Budayawan Buton, Wawancara, Baubau, tanggal 23-

${ }^{61}$ Tarimana dalam M. Alifuddin, Islam Buton (Interaksi antara Islam dengan Budaya Lokal) Seri Disertasi (Cet. I; Jakarta: Badan Litbang dan Diklat Departemen Agama RI, 2007), h. 108. 
Pelaksanaan pendidikan Islam di Zawiyah bersifat tradisional dan sentralistik, karena menjadikan seorang mursyid sebagai figur utama dalam proses pembelajaran. Materi ajarnya hanya dalam bentuk jadwal yang telah disepakati bersama. Materi pembelajarannya memuat dua unsur yaitu ilmu tasawuf, dan ilmu fikih. Ilmu tasawuf yang meliputi tasawuf tarekat dan tasawuf teosofi atau falsafi. Sedangkan ilmu fikih mencakup kaidah ușūl dan fikih, atau meliputi ibadah mahdah dan muamalah termasuk didalamnya sastra dan pemerintahan. Sedangkan metode pembelajaran di Zawiyah disesuaikan dengan materi pembelajarannya. Metode yang paling menonjol adalah metode suluk dalam tasawuf. Sementara Hubungan antara mursyid dan murid didalam Zawiyah dilandasi semangat kepercayaan yang diimplementasikan melalui tingkah laku dan perbuatan seharihari.

Peran Zawiyah terhadap perkembangan pendidikan Islam di Buton sebagai wadah dalam menanamkan kesadaran berfikir tentang hakekat keislaman bagi masyarakat Buton yang ada di wilayah keraton, sekaligus sebagai bentuk syiar ajaran Islam yang mesti melekat dalam kehidupan masyarakat Buton secara keseluruhan.

\section{B. Implikasi Penelitian}

Kajian tentang penelitian pendidikan Islam di Zawiyah pada masa kesultanan Buton abad ke-19 ini diharapkan dapat menjadi tambahan pemikiran dalam khazana ilmu pengetahuan tentang lembaga pendidikan Islam di Buton. Juga menjadi pijakan untuk menelaah tradisi keislaman yang diwariskan oleh para leluhur di Buton serta diharapkan dapat memberi masukan kepada insan akademik, budayawan dan sejarawan khususnya bagi peneliti selanjutnya. 


\section{DAFTAR PUSTAKA}

Abdullah, Muh. Naskah Keagamaan dan Relevansinya dengan proses Islamisasi Buton Abad ke-14 hingga 16: Naskah Dunia. Bau-Bau: Penerbit Respect, 2009.

Aidrus, Tazikri, dalam SBF: 213 ditranskrip dan diindonesiakan oleh A. Mulku Zahari bekerjasama dengan KITLV Jakarta. Baubau: stensilan, 1985.

Alifuddin, M. Islam Buton (Interaksi antara Islam dengan Budaya Lokal) Seri Disertasi. Cet. I; Jakarta: Badan Litbang dan Diklat Departemen Agama RI, 2007.

Al-Nuaymi. "Al-Dāris fĩ Tārikh al-Madāris. Beirut: Dār al-Kutūb al-'Ilmīyah, 1990.

Anceaux, J.C. Wolio dictionary-Wolio-English-Indonesia. Foris Publication Holand, 1987.

Asari, Hasan. Menyingkap Keemasan Islam: Kajian atas Lembaga-lembaga Pendidikan Isla. Bandung: Mizan, 1994.

Barkey Jonathan. The Transmission of Knowledge in Medieval Cairo; a Social History of Islamic Education. Pringeton: Pringeton Uneversity Press, 1992.

Corteseo, Armado. The Suma Oriental of Tome Pires. Vol. 1. 1944.

La Niampe, Syair Ajonga Inda Malusa: Pengantar dan Suntingan Naskah Kendari: FKIP Unhalu, 2009.

Ligtvoet. "Beschrijing en Geschiedenis van Buton", BKI. Vol. 26. 1878.

Little, Donald P. "The Nature Of Khanqah, Ribath and Zawiyah" Islamic Studies To Charles Adams. ed. Leiden: E.J. Brill, 1990.

Mahrudin. "Kontribusi Falsafah Pobinci-Binciki Kuli Masyarakat Islam Buton Bagi Dakwah Islam Untuk Membangun Karakter Generasi Muda Indonesia". Jurnal Dakwah, Vol. XV, No. 2. 2014.

Moersidi. "Mengungkap Nilai-Nilai Kepemimpinan Buton Sebelum dan Sesudah Datangnya Agama Islam", Makalah Pada Kerukunan Mahasiswa Indonesia Buton. 1990. 
Partanto, Pius A dan M. Dahlan al-Barry. Kamus Ilmiah Populer. Surabaya: Arkaloka, 2001.

Pramudito, Bambang. Kitab Negara Kartagama: Sejarah Tata Pemerintahan dan Peradilan Keraton Majapahit. Yogyakarta: Gelombang Pasang, 2006.

Trimigham, J. Spencer. The Sufi Orders in Islam, ter. Lukman Hakim, Mazhab Sufi. Bandung: Pustaka, 199.

Warson, Ahmad. Al-Munawwir, Kamus Arab Indonesia, telaah. Ali Ma’șun, Zainal Abidin Munawwir. Cet. XIV; Surabaya, Pustaka Progres, 1997.

Yunus, Abd. Rahim. Posisi Tasawuf dalam Sistem Kekuasaan di Kesultanan Buton pada Abad ke-19. Jakarta: Indonesian-Netherlands Coorperation in Islamic Studies (INIS), 1995.

Zahari A. Mulku. Sejarah dan Adat fì Dār al-Butuni. Jilid. I,II,III. Jakarta: Depdikbud, 1977.

- "Sejarah Masuknya Islam di Buton dan Perkembangannya" Makalah Disampaikan dalam Seminar Sejarah Masuknya Islam di Buton yang Diadakan oleh Fakultas Tarbiyah, IAIN Aluaddin Baubau pada Tanggal 1 Maret. 1990. 